\title{
In Memoriam Claudina Rodrigues-Pousada (1941-2021), a dedicated woman in science
}

\section{Olivier Bensaude ${ }^{1}$}

Accepted: 12 March 2021 / Published online: 2 April 2021

(C) Cell Stress Society International 2021

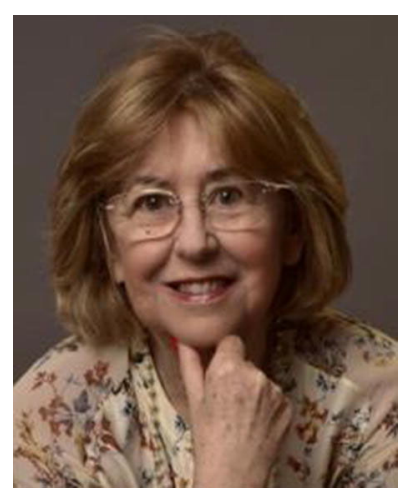

Claudina Rodrigues-Pousada (photo courtesy of ITQB NOVA).

Claudina Rodrigues-Pousada passed away on March 2nd, after a fierce twenty-year fight against tumors. But her enthusiasm still vibrates in the minds of her countless former students, colleagues and friends.

Claudina was born in 1941 in Tadim, a small village in the North of Portugal (Rodrigues-Pousada, 2016). Her mother was a schoolteacher and her father was in business selling cars. After graduating from the University of Pharmacy in Porto in 1968, she decided to go into research and applied to the Biology Department of the Gulbenkian Institute in Oeiras near Lisbon. In those days, it was the only place in Portugal where research in molecular biology was done. There, after starting a $\mathrm{PhD}$ working on ribosomes and publishing two

Olivier Bensaude

bensaude@bio.ens.psl.eu

1 Institut de Biologie de l'Ecole Normale Supérieure (IBENS), Ecole Normale Supérieure, CNRS, INSERM, PSL Research University, 46 rue d'Ulm, 75005 Paris, France papers, she thought it would be useful to go abroad to be exposed to cutting-edge research. From 1973 on, Claudina spent 3 years at the Institut de Biologie Physico-Chimique in Paris in the laboratory of Marianne Grunberg-Manago working on ribosomes in Tetrahymena pyriformis. In 1979, she defended her $\mathrm{PhD}$ at University Paris VII. Immediately thereafter, she started her own laboratory at the Gulbenkian Institute using Tetrahymena as a model system to investigate tubulin biosynthesis. This is how she first came upon the CCT chaperonin, and from there into stress gene regulation.

Claudina and I met in 1983 when she invited me to present our unpublished data on heat-shock protein expression during early mouse embryogenesis. We have been friends and colleagues ever since. In later years, Claudina switched from Tetrahymena to the yeast Saccharomyces cerevisiae, contributing to the first sequencing of the yeast genome. She then focused on the yeast AP-1 and AP-1 like transcription factors that are involved in stress responses. In the meantime, she became head of the Molecular Genetics Laboratory and later of 
the Unit of Genetic Engineering of Gulbenkian Institute. In 2000, she left the Gulbenkian Institute and joined the Institute de Tecnologia Química e Biológica (ITQB) also in Oeiras, to establish the "Genomics and Stress laboratory". In addition to the yeast model, she turned to the anaerobic bacteria Desulfovibrio gigas. She coordinated its whole genome sequencing and investigated various genes involved in its stress responses.

Claudina gained international recognition resulting in collaborations with many teams abroad. She was a lifetime member of the Cell Stress Society International and was the principal organizer of the international congress of the Society held in Tomar, Portugal in 2003. She was elected a Senior Fellow by the Cell Stress Society International and was elected a member of the European Molecular Biology Organization (EMBO). As a professor at the Abel Salazar Institute of Biomedical Sciences in Porto and through the "super doctor" course at the Gulbenkian Institute, Claudina actively promoted molecular biology teaching in Portugal. She mentored over 30 $\mathrm{PhDs}$ and supported many young colleagues in their careers. She was a creative scientist whose energy also led her to take responsibilities in the scientific community. Beginning with the Portuguese Biochemical Society (Sociedade Portuguesa de Bioquímica - SPB) she subsequently became very active in the Federation of European Biological Societies (FEBS) of which she was president 2003-2004.

A staunch opponent of the Salazar dictatorship, Claudina remained close to the Portuguese Communist Party after the 1974 revolution. She was also very proud of her three sons and her parents. She will be remembered as an energetic and affectionate woman, dedicated to science, to her students, to her friends and to her family.

\section{Reference}

Rodrigues-Pousada C (2016) The birth of enthusiasm and passion for science. FEMS Yeast Res 16(5):fow057. https://doi.org/10.1093/ femsyr/fow057 Epub 2016 Jul 2. PMID: 27371857

Publisher's note Springer Nature remains neutral with regard to jurisdictional claims in published maps and institutional affiliations. 